\title{
Shewanella gaetbuli sp. nov., a slight halophile isolated from a tidal flat in Korea
}

\author{
Correspondence \\ Yong-Ha Park \\ yhpark@kribb.re.kr
}

\author{
Jung-Hoon Yoon, ${ }^{1}$ Kook Hee Kang, ${ }^{2}$ Tae-Kwang Oh ${ }^{1}$ \\ and Yong-Ha Park ${ }^{1,3}$ \\ ${ }^{1}$ Korea Research Institute of Bioscience and Biotechnology (KRIBB), PO Box 115, Yusong,
Taejon, Korea \\ 2Department of Food and Life Science, Sungkyunkwan University, Chunchun-dong 300, \\ Jangan-gu, Suwon, Korea
${ }^{3}$ National Research Laboratory of Molecular Ecosystematics, Institute of Probionic, Probionic Corporation, Bio-venture Center, Korea Research Institute of Bioscience and Biotechnology (KRIBB), PO Box 115, Yusong, Taejon, Korea

A Gram-negative, motile, non-spore-forming, rod-shaped strain, TF- $27^{\top}\left(=\mathrm{KCCM} 41648^{\top}=\mathrm{JCM}\right.$ $11814^{\top}$ ), was isolated from a tidal flat in Korea. This organism grew well at $25-35^{\circ} \mathrm{C}$, with optimum growth at $30^{\circ} \mathrm{C}$. Strain TF- $27^{\top}$ grew optimally in the presence of $2 \% \mathrm{NaCl}$; it did not grow without $\mathrm{NaCl}$ or in the presence of $>8 \% \mathrm{NaCl}$. Strain TF- $27^{\top}$ simultaneously contained both menaquinones and ubiquinones as isoprenoid quinones. The predominant menaquinone was MK-7 and the predominant ubiquinones were $Q-7$ and Q-8. The major fatty acids in strain TF-27 were iso- $\mathrm{C}_{15: 0}(20 \cdot 6 \%)$ and iso- $\mathrm{C}_{15: 0} 2-\mathrm{OH}$ and/or $\mathrm{C}_{16: 1} \omega 7 c(21 \cdot 1 \%)$. The DNA G+C content of strain TF- $27^{\top}$ was 42 mol\%. Phylogenetic analyses based on $16 \mathrm{~S}$ rDNA sequences showed that strain TF- $27^{\top}$ falls within the radiation of the cluster that is encompassed by the genus Shewanella. Levels of $16 \mathrm{~S}$ rDNA sequence similarity between strain TF- $27^{\top}$ and the type strains of Shewanella species were $93 \cdot 2-96 \cdot 8 \%$. On the basis of phenotypic properties and phylogenetic data, strain TF- $27^{\top}$ should be placed in the genus Shewanella as a novel species, for which the name Shewanella gaetbuli sp. nov. is proposed.
The genus Shewanella was created by reclassification of two species that were assigned previously to the genus Alteromonas, Alteromonas putrefaciens and Alteromonas hanedai (MacDonell \& Colwell, 1985). There are 22 Shewanella species with validly published names at the time of writing. The genus Shewanella accommodates Gram-negative, facultatively anaerobic, straight or curved rods that belong to the Proteobacteria (Stackebrandt et al., 1988; Venkateswaran et al., 1999; Boone et al., 2001). This genus is also characterized by simultaneously having menaquinones and ubiquinones, although not all Shewanella species have been analysed (Venkateswaran et al., 1999; Bozal et al., 2002). The genus Shewanella is affiliated phylogenetically to the $\gamma$-subclass of the Proteobacteria (Anzai et al., 2000). Shewanella species have been isolated from a variety of sources, including aquatic or marine

\footnotetext{
Abbreviations: FAME, fatty acid methyl ester; TEM, transmission electron microscopy.

The GenBank/EMBL/DDBJ accession number for the 16S rDNA sequence of strain TF-27 ${ }^{\top}$ is AY 190533.

A full version of the phylogenetic tree shown in Fig. 1 is available as supplementary material in IJSEM Online.
}

environments (Nealson et al., 1991; Ivanova et al., 2001; Bozal et al., 2002), clinical samples (Nozue et al., 1992; Brink et al., 1995; Venkateswaran et al., 1999), sediments (Myers \& Nealson, 1988) and oilfield fluids (Semple \& Westlake, 1987). Shewanella species have been strongly implicated as opportunistic pathogens of humans and aquatic animals (Aguirre et al., 1994; Brink et al., 1995) and as causal agents of the spoilage of proteinaceous foods (Jorgensen \& Huß, 1989). Shewanella species have also been known to be important in the context of bioremediation, because of their considerable potential for co-metabolic bioremediation of halogenated organic pollutants (Petrovskis et al., 1994), destructive souring of crude petroleum (Semple \& Westlake, 1987) and dissimilatory reduction of manganese and iron oxides (Myers \& Nealson, 1988), uranium (Lovley \& Phillips, 1988) and other compounds (Perry et al., 1993; Kostka et al., 1996). In this study, we describe a Gramnegative, moderately halophilic, rod-shaped strain, TF- $27^{\mathrm{T}}$, which was isolated from a tidal flat in Korea. From the results of $16 \mathrm{~S}$ rDNA sequence comparison, this organism was considered to be related phylogenetically to the genus Shewanella. Accordingly, the aim of the present work was to establish the exact taxonomic position of strain TF- $27^{\mathrm{T}}$ by using a combination of polyphasic taxonomic data. 
Strain $\mathrm{TF}-27^{\mathrm{T}}$ was isolated from a tidal flat near the city of Mokpo, Korea, by the dilution-plating technique on marine agar 2216 (MA; Difco). Cell morphology was examined by light microscopy (Nikon E600) and transmission electron microscopy (TEM). Flagellum type was examined by TEM, using cells from exponentially growing cultures. Cells were stained negatively with $1 \%(\mathrm{w} / \mathrm{v})$ phosphotungstic acid and grids were examined after airdrying by using a Philips CM-20 transmission electron microscope. Gram-reaction was determined by using a Gram Stain kit (bioMérieux) according to the manufacturer's instructions. The $\mathrm{pH}$ range for growth was determined in marine broth 2216 (MB; Difco) with $\mathrm{pH}$ adjusted to $5 \cdot 0,5 \cdot 5,6 \cdot 0,6 \cdot 5,7 \cdot 0,7 \cdot 5,8 \cdot 0,8 \cdot 5$ and $9 \cdot 0$. Growth at various $\mathrm{NaCl}$ concentrations was investigated in $\mathrm{MB}$. Growth in the absence of $\mathrm{NaCl}$ was investigated in trypticase soy broth to which $\mathrm{NaCl}$ had not been added. Growth at various temperatures was measured on $\mathrm{MA}$ at $4-45^{\circ} \mathrm{C}$. Catalase activity was determined by bubble production in $3 \%(\mathrm{v} / \mathrm{v})$ hydrogen peroxide solution. Oxidase activity was determined by oxidation of $1 \%(\mathrm{w} / \mathrm{v}) p$-aminodimethylaniline oxalate. Hydrolysis of casein, starch and Tween 80 was determined as described by Cowan \& Steel (1965). Hydrolysis of aesculin was determined according to the method of Lanyi (1987). Hydrolysis of hypoxanthine, tyrosine and xanthine was performed on MA by using substrate concentrations that were described by Cowan \& Steel (1965). Hydrolysis of gelatin and nitrate reduction were determined as described by Lanyi (1987), with the modification that artificial sea water was used, which contained [(1 distilled water $)^{-1}$ ]: $23.6 \mathrm{~g} \mathrm{NaCl}, 0.64 \mathrm{~g} \mathrm{KCl}, 4.53 \mathrm{~g}$ $\mathrm{MgCl}_{2} \cdot 6 \mathrm{H}_{2} \mathrm{O}, 5.94 \mathrm{~g} \mathrm{MgSO}_{4} .7 \mathrm{H}_{2} \mathrm{O}$ and $1.3 \mathrm{~g} \mathrm{CaCl}_{2} \cdot 2 \mathrm{H}_{2} \mathrm{O}$ (Levring, 1946). Hydrolysis of birch wood xylan (Sigma) was determined on solid marine salts basal medium (Baumann \& Baumann, 1981) that contained $0.5 \%(\mathrm{w} / \mathrm{v})$ xylan as the sole carbon source. $\mathrm{H}_{2} \mathrm{~S}$ production was tested as described by Bruns et al. (2001). Haemolytic activity was recorded on MA with $5 \%$ defibrinated sheep blood. The API ZYM system (bioMérieux) was used to determine enzyme activity. Acid production from carbohydrates was determined as described by Leifson (1963). Utilization of substrates as sole carbon and energy sources was tested as described by Baumann \& Baumann (1981). Growth under anaerobic conditions was determined after incubation in an anaerobic chamber on anaerobically prepared MA.

Cell biomass of strain $\mathrm{TF}-27^{\mathrm{T}}$ for respiratory lipoquinone analysis and for DNA extraction was obtained from $\mathrm{MB}$ cultures at $30^{\circ} \mathrm{C}$. For fatty acid methyl ester (FAME) analysis, cell mass of strain $\mathrm{TF}-27^{\mathrm{T}}$ was obtained from agar plates after cultivation for 3 days at $30{ }^{\circ} \mathrm{C}$ on MA. Isoprenoid quinones were extracted and analysed as described by Komagata \& Suzuki (1987), using reverse-phase HPLC. For quantitative analysis of cellular fatty acid compositions, a loop of cell mass was harvested and FAMEs were prepared and identified by following the instructions of the Microbial Identification system (MIDI). Chromosomal DNA was isolated and purified according to a method described previously (Yoon et al., 1996), except that ribonuclease T1 was used with ribonuclease A. DNA G + C content was determined by the method of Tamaoka \& Komagata (1984). DNA was hydrolysed and the resultant nucleotides were analysed by reverse-phase HPLC. 16S rDNA was amplified by PCR using two universal primers, as described previously (Yoon et al., 1998). Sequencing of the amplified 16S rDNA and phylogenetic analysis were performed as described by Yoon et al. (2003).

Morphological, physiological and biochemical characteristics of strain $\mathrm{TF}-27^{\mathrm{T}}$ are given in the species description below and in Table 1, together with those of other Shewanella species. Strain TF- $27^{\mathrm{T}}$ simultaneously contained both menaquinones and ubiquinones as isoprenoid quinones. This profile has been also observed in other Shewanella species (Nogi et al., 1998; Venkateswaran et al., 1999; Bozal et al., 2002). Strain TF- $27^{\mathrm{T}}$ contained MK-7 (approx. 90\%) as the predominant menaquinone. The predominant ubiquinones detected in strain $\mathrm{TF}-27^{\mathrm{T}}$ were Q-7 and Q-8, at peak area ratios of approximately 45 and $52 \%$, respectively. Strain $\mathrm{TF}-27^{\mathrm{T}}$ had a cellular fatty acid profile that contained large amounts of straight-chain, branched, unsaturated and hydroxy fatty acids. It contained the following major fatty acids: iso- $\mathrm{C}_{15: 0}, 20 \cdot 6 \%$; iso- $\mathrm{C}_{15: 0}$ $2-\mathrm{OH}$ and/or $\mathrm{C}_{16: 1} \omega 7 c, 21 \cdot 1 \%$; iso- $\mathrm{C}_{13: 0}, 9 \cdot 4 \%$; $\mathrm{C}_{16: 0}$, $8.4 \% ; \mathrm{C}_{17: 1} \omega 8 c, 6 \cdot 4 \%$; iso- $\mathrm{C}_{13: 0} 3-\mathrm{OH}, 6.1 \% ; \mathrm{C}_{15: 0}$, $3 \cdot 8 \% ; \mathrm{C}_{12: 0}, 3 \cdot 1 \% ; \mathrm{C}_{18: 1} \omega 7 c, 2 \cdot 5 \%$; iso- $\mathrm{C}_{14: 0}, 2 \cdot 0 \%$. The DNA G $+\mathrm{C}$ content of strain TF- $27^{\mathrm{T}}$ was $42 \mathrm{~mol} \%$, which is in the range for known Shewanella species (Table 1).

The almost-complete 16S rDNA sequence of strain TF- $27^{\mathrm{T}}$, comprising $1497 \mathrm{nt}$ (approx. 96\% of the Escherichia coli $16 \mathrm{~S}$ rRNA gene sequence), was determined directly after PCR amplification. Phylogenetic analysis based on $16 \mathrm{~S}$ rDNA sequences showed that strain TF- $27^{\mathrm{T}}$ was within the radiation of the cluster that comprised Shewanella species. In a phylogenetic tree based on the neighbourjoining algorithm, strain $\mathrm{TF}-27^{\mathrm{T}}$ occupied an independent lineage within the evolutionary radiation that was encompassed by the genus Shewanella, particularly within the clade that comprised Shewanella oneidensis, Shewanella putrefaciens, Shewanella baltica, Shewanella livingstonensis, Shewanella frigidimarina, Shewanella denitrificans, Shewanella olleyana and Shewanella japonica (Fig. 1). The relationship between this clade and the cluster that comprised other Shewanella species was supported by a high bootstrap resampling value (Fig. 1). Strain $\mathrm{TF}-27^{\mathrm{T}}$ exhibited $16 \mathrm{~S}$ rDNA similarity levels of $93 \cdot 2-96 \cdot 8 \%$ to the type strains of Shewanella species with validly published names, and levels of $<91.6 \%$ to other species used in the phylogenetic analysis.

The result of $16 \mathrm{~S}$ rDNA sequence analysis indicated that strain $\mathrm{TF}-27^{\mathrm{T}}$ had closest phylogenetic affinity with the $\gamma$-Proteobacteria, and particularly to the genus Shewanella. Phylogenetic inference based on 16S rDNA sequences revealed that strain $\mathrm{TF}-27^{\mathrm{T}}$ falls within the evolutionary clade that comprises Shewanella species (Fig. 1). 


\section{Table 1. Phenotypic characteristics of strain TF- $27^{\top}$ and related Shewanella species}

Taxa: 1, strain TF-27 $7^{\mathrm{T}}$; 2, Shewanella algae; 3, Shewanella amazonensis; 4, S. baltica; 5, S. frigidimarina; 6, S. japonica; 7, S. livingstonensis; 8, S. oneidensis; 9, S. putrefaciens. All species have a single polar flagellum, are positive for growth at $3 \% \mathrm{NaCl}$, catalase and oxidase and are Gram-negative. Data for strain TF- $27^{\mathrm{T}}$ are from this study; data for other taxa are from Nogi et al. (1998), Venkateswaran et al. (1999) and Ivanova et al. (2001). +, Positive reaction; -, negative reaction; v, variable reaction; ND, not determined; $n$, no. strains.

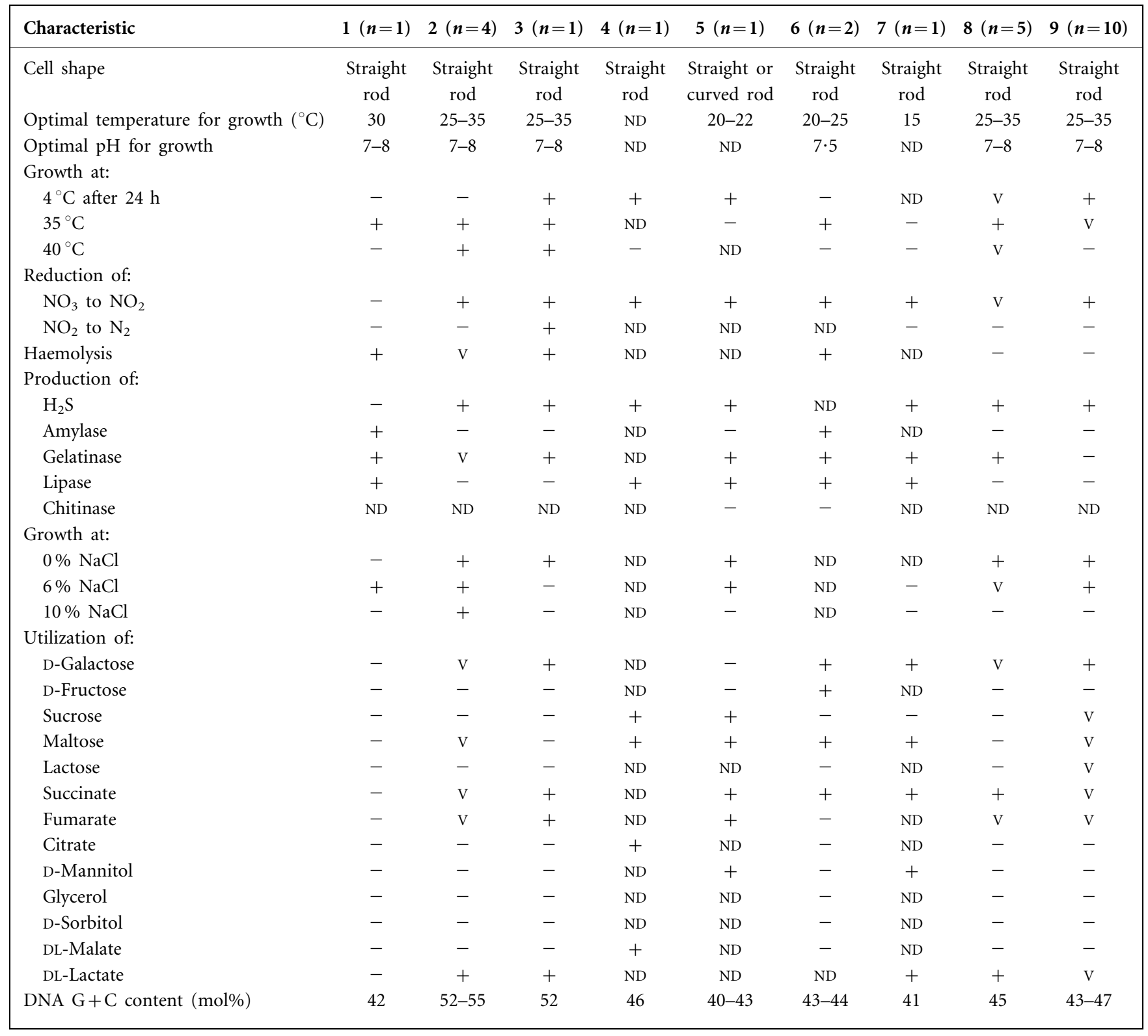

Chemotaxonomic analysis supports the result of the monothetic classification, based on $16 \mathrm{~S}$ rDNA sequence analysis. The cellular fatty acid profile of strain $\mathrm{TF}-27^{\mathrm{T}}$ was found to be similar to those that have been described previously for Shewanella species (Bowman et al., 1997; Venkateswaran et al., 1999; Ivanova et al., 2001; Bozal et al., 2002). Strain TF- $27^{\mathrm{T}}$ was found to have an isoprenoid quinone pattern similar to those of Shewanella species: these species, as well as strain $\mathrm{TF}-27^{\mathrm{T}}$, simultaneously contain both menaquinones and ubiquinones, although their compositions are variable, depending on strains or species (Nogi et al., 1998; Venkateswaran et al., 1999; Bozal et al., 2002). Accordingly, in view of combined morphological, phenotypic, chemotaxonomic and phylogenetic data, strain TF- $27^{\mathrm{T}}$ can be classified as a member of the genus Shewanella. Strain TF- $27^{\mathrm{T}}$ can be differentiated from phylogenetically related Shewanella species by some physiological and biochemical characteristics, such as growth temperature, $\mathrm{NaCl}$ tolerance and the ability to utilize certain substrates (Table 1). 16S rDNA similarity levels between strain $\mathrm{TF}-27^{\mathrm{T}}$ and the type strains of other Shewanella species are low enough $(93 \cdot 2-96 \cdot 8 \%)$ to categorize strain 


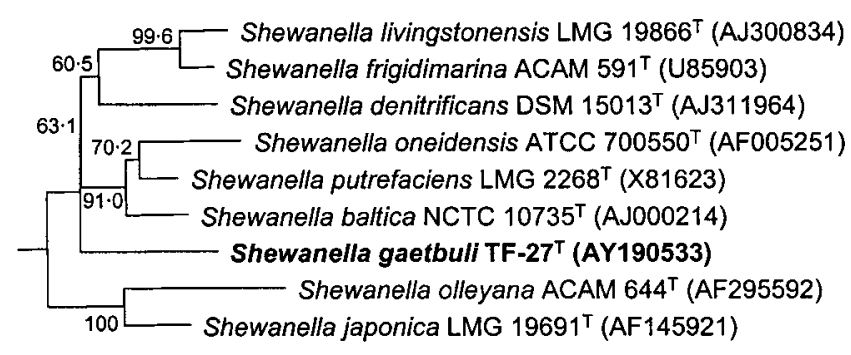

$\underline{0.01}$

Fig. 1. Neighbour-joining tree showing the phylogenetic position of strain TF- $27^{\top}$ and representatives of other related taxa, based on 16S rDNA sequences. Bootstrap values (expressed as percentages of 1000 replications) of $>50 \%$ are shown at branch-points. The full tree from which Fig. 1 was taken is available as supplementary material in IJSEM Online. Bar, 0.01 substitutions per nucleotide position.

$\mathrm{TF}-27^{\mathrm{T}}$ as a species that is distinct from previously described Shewanella species (Stackebrandt \& Goebel, 1994). Therefore, on the basis of these data, strain TF- $27^{\mathrm{T}}$ should be placed in the genus Shewanella as a novel species, for which we propose the name Shewanella gaetbuli sp. nov.

\section{Description of Shewanella gaetbuli sp. nov.}

Shewanella gaetbuli (gaet.bu'li. N.L. gen. n. gaetbuli of gaetbul, the Korean name for a tidal flat).

Cells are straight rods, $0 \cdot 5-0 \cdot 7 \times 1 \cdot 5-3 \cdot 0 \mu \mathrm{m}$ on MA. Gramstain reaction is negative. Non-spore-forming. Motile by means of a single polar flagellum. Colonies are smooth, glistening, circular to slightly irregular, flat to raised, light brown in colour and 2.0-4.0 $\mathrm{mm}$ in diameter after 3 days incubation at $30^{\circ} \mathrm{C}$ on MA. Growth occurs at 4 and $39^{\circ} \mathrm{C}$, but not above $40^{\circ} \mathrm{C}$. Growth is observed at $\mathrm{pH} 5 \cdot 0$, but not at $\mathrm{pH} 4 \cdot 5$. Optimal growth occurs in the presence of $2 \%$ $\mathrm{NaCl}$; no growth occurs in the presence of $>8 \% \mathrm{NaCl}$. Growth occurs under anaerobic conditions on MA. Aesculin, casein, gelatin, starch and Tween 80 are hydrolysed. Hypoxanthine, tyrosine, xanthine and xylan (birch wood) are not hydrolysed. When assayed with the API ZYM system, alkaline phosphatase, esterase (C4), esterase lipase (C8), $\alpha$-chymotrypsin, acid phosphatase, naphtholAS-BI-phosphohydrolase and $N$-acetyl- $\beta$-glucosaminidase are present and leucine arylamidase is weakly present, but lipase (C14), valine arylamidase, cystine arylamidase, trypsin, $\alpha$-galactosidase, $\beta$-galactosidase, $\beta$-glucuronidase, $\alpha$-glucosidase, $\beta$-glucosidase, $\alpha$-mannosidase and $\alpha$-fucosidase are absent. Acid is produced from myo-inositol, D-ribose and D-trehalose. Acid is not produced from L-arabinose, D-cellobiose, D-fructose, D-galactose, D-glucose, lactose, maltose, D-mannose, D-melezitose, melibiose, D-raffinose, L-rhamnose, stachyose, sucrose, D-xylose, adonitol, D-mannitol or D-sorbitol. Both menaquinones and ubiquinones are present; predominant menaquinone is MK-7 and predominant ubiquinones are Q-7 and Q-8. Major fatty acids are iso- $\mathrm{C}_{15: 0}$ and iso- $\mathrm{C}_{15: 0} \quad 2-\mathrm{OH}$ and/or $\mathrm{C}_{16: 1} \omega 7 c$. DNA G+C content is $42 \mathrm{~mol} \%$ (HPLC). Other characteristics are given in Table 1.

The type strain is TF- $27^{\mathrm{T}}\left(=\mathrm{KCCM} 41648^{\mathrm{T}}=\mathrm{JCM} 11814^{\mathrm{T}}\right)$. Isolated from a tidal flat near Mokpo, Korea.

\section{Acknowledgements}

This work was supported by the NRL research programme (grants M10104000294-01J000012800 and M10104000294-01J0 00012811) and the 21C Frontier programme of Microbial Genomics and Applications (grant MG02-0401-001-1-0-0) from the Ministry of Science and Technology (MOST) of the Republic of Korea.

\section{References}

Aguirre, A. A., Balazs, G. H., Zimmerman, B. \& Spraker, T. R. (1994). Evaluation of Hawaiian green turtles (Cheledonia mydas) for potential pathogens associated with fibropapillomas. $J$ Wildl Dis 30, 8-15.

Anzai, Y., Kim, H., Park, J.-Y., Wakabayashi, H. \& Oyaizu, H. (2000). Phylogenetic affiliation of the pseudomonads based on 16S rRNA sequence. Int J Syst Evol Microbiol 50, 1563-1589.

Baumann, P. \& Baumann, L. (1981). The marine Gram-negative eubacteria: genera Photobacterium, Beneckea, Alteromonas, Pseudomonas, and Alcaligenes. In The Prokaryotes. A Handbook on Habitats, Isolation, and Identification of Bacteria, pp. 1302-1331. Edited by M. P. Starr, H. Stolp, H. G. Trüper, A. Balows \& H. G. Schlegel. Berlin: Springer.

Boone, D. R., Castenholz, R. W. \& Garrity, G. M. (2001). Bergey's Manual of Systematic Bacteriology, 2nd edn, vol. 1. New York: Springer.

Bowman, J. P., McCammon, S. A., Nichols, D. S., Skerratt, J. H., Rea, S. M., Nichols, P. D. \& McMeekin, T. A. (1997). Shewanella gelidimarina sp. nov. and Shewanella frigidimarina sp. nov., novel Antarctic species with the ability to produce eicosapentaenoic acid $(20: 5 \omega 3)$ and grow anaerobically by dissimilatory $\mathrm{Fe}(\mathrm{III})$ reduction. Int J Syst Bacteriol 47, 1040-1047.

Bozal, N., Montes, M. J., Tudela, E., Jiménez, F. \& Guinea, J. (2002). Shewanella frigidimarina and Shewanella livingstonensis sp. nov. isolated from Antarctic coastal areas. Int J Syst Evol Microbiol 52, 195-205.

Brink, A. J., van Straten, A. \& van Rensburg, A. J. (1995). Shewanella (Pseudomonas) putrefaciens bacteremia. Clin Infect Dis 20, 1327-1332.

Bruns, A., Rohde, M. \& Berthe-Corti, L. (2001). Muricauda ruestringensis gen. nov., sp. nov., a facultatively anaerobic, appendaged bacterium from German North Sea intertidal sediment. Int $J$ Syst Evol Microbiol 51, 1997-2006.

Cowan, S. T. \& Steel, K. J. (1965). Manual for the Identification of Medical Bacteria. London: Cambridge University Press.

Ivanova, E. P., Sawabe, T., Gorshkova, N. M., Svetashev, V. I., Mikhailov, V. V., Nicolau, D. V. \& Christen, R. (2001). Shewanella japonica sp. nov. Int J Syst Evol Microbiol 51, 1027-1033.

Jorgensen, B. R. \& Huß, H. H. (1989). Growth and activity of Shewanella putrefaciens isolated from spoiling fish. Int $J$ Food Microbiol 9, 51-62.

Komagata, K. \& Suzuki, K. (1987). Lipid and cell wall analysis in bacterial systematics. Methods Microbiol 19, 161-206.

Kostka, J. E., Stucki, J. W., Nealson, K. H. \& Wu, J. (1996). Reduction of structural $\mathrm{Fe}(\mathrm{III})$ in smectite by a pure culture of Shewanella putrefaciens strain MR-1. Clays Clay Miner 44, 522-529. 
Lanyi, B. (1987). Classical and rapid identification methods for medically important bacteria. Methods Microbiol 19, 1-67.

Leifson, E. (1963). Determination of carbohydrate metabolism of marine bacteria. J Bacteriol 85, 1183-1184.

Levring, T. (1946). Some culture experiments with Ulva and artificial seawater. Kungl Fysiogr Sallsk Lund Forh 16, 45-56.

Lovley, D. R. \& Phillips, E. J. P. (1988). Novel mode of microbial energy metabolism: organic carbon oxidation coupled to dissimilatory reduction of iron or manganese. Appl Environ Microbiol 54, 1472-1480.

MacDonell, M. T. \& Colwell, R. R. (1985). Phylogeny of the Vibrionaceae, and recommendation for two new genera, Listonella and Shewanella. Syst Appl Microbiol 6, 171-182.

Myers, C. R. \& Nealson, K. H. (1988). Bacterial manganese reduction and growth with manganese oxide as the sole electron acceptor. Science 240, 1319-1321.

Nealson, K. H., Myers, C. R. \& Wimpee, B. (1991). Isolation and identification of manganese reducing bacteria, and estimates of microbial manganese reducing potential in the Black Sea. Deep Sea Res 38, S907-S920.

Nogi, Y., Kato, C. \& Horikoshi, K. (1998). Taxonomic studies of deep-sea barophilic Shewanella strains and description of Shewanella violacea sp. nov. Arch Microbiol 170, 331-338.

Nozue, H., Hayashi, T., Hashimoto, Y., Ezaki, T., Hamasaki, K., Ohwada, K. \& Terawaki, Y. (1992). Isolation and characterization of Shewanella alga from human clinical specimens and emendation of the description of S. alga Simidu et al., 1990, 335. Int J Syst Bacteriol 42, 628-634.

Perry, K. A., Kostka, J. E., Luther, G. W., III \& Nealson, K. H. (1993). Mediation of sulfur speciation by a Black Sea facultative anaerobe. Science 259, 801-803.
Petrovskis, E. A., Vogel, T. M. \& Adriaens, P. (1994). Effects of electron acceptors and donors on transformation of tetrachloromethane by Shewanella putrefaciens MR-1. FEMS Microbiol Lett 121, 357-364.

Semple, K. M. \& Westlake, D. W. S. (1987). Characterization of iron-reducing Alteromonas putrefaciens strains from oil field fluids. Can J Microbiol 33, 366-371.

Stackebrandt, E. \& Goebel, B. M. (1994). Taxonomic note: a place for DNA-DNA reassociation and 16S rRNA sequence analysis in the present species definition in bacteriology. Int J Syst Bacteriol 44, 846-849.

Stackebrandt, E., Murray, R. G. E. \& Trüper, H. G. (1988). Proteobacteria classis nov., a name for the phylogenetic taxon that includes the "purple bacteria and their relatives". Int J Syst Bacteriol 38, 321-325.

Tamaoka, J. \& Komagata, K. (1984). Determination of DNA base composition by reverse-phase high-performance liquid chromatography. FEMS Microbiol Lett 25, 125-128.

Venkateswaran, K., Moser, D. P., Dollhopf, M. E. \& 10 other authors (1999). Polyphasic taxonomy of the genus Shewanella and description of Shewanella oneidensis sp. nov. Int J Syst Bacteriol 49, 705-724.

Yoon, J.-H., Kim, H., Kim, S.-B., Kim, H.-J., Kim, W. Y., Lee, S. T., Goodfellow, M. \& Park, Y.-H. (1996). Identification of Saccharomonospora strains by the use of genomic DNA fragments and rRNA gene probes. Int J Syst Bacteriol 46, 502-505.

Yoon, J.-H., Lee, S. T. \& Park, Y.-H. (1998). Inter- and intraspecific phylogenetic analysis of the genus Nocardioides and related taxa based on 16S rDNA sequences. Int J Syst Bacteriol 48, 187-194.

Yoon, J.-H., Kim, I.-G., Shin, D.-Y., Kang, K. H. \& Park, Y.-H. (2003). Microbulbifer salipaludis sp. nov., a moderate halophile isolated from a Korean salt marsh. Int J Syst Evol Microbiol 53, 53-57. 